\title{
Handling and Curing Characteristics of Cut-Strip Tobacco. Part 2: Effect of Yellowing Time and Drying Potential*
}

\author{
by \\ W.H. Johnson ${ }^{1}$, J.H. Young ${ }^{1}$,W.W. Weeks ${ }^{2}$, G.H. Ellington ${ }^{l}$ and J.C. Tutor ${ }^{l}$ \\ ${ }^{I}$ North Carolina State University, Department of Biological and Agricultural Engineering, Raleigh, North Carolina, USA. \\ ${ }^{2}$ Department of Crop Science, North Carolina State University, Raleigh, NC 27695, USA
}

\section{SUMMARY}

This paper presents Part 2 of a study on comparative handling and curing characteristics of cut-strip vs. wholeleaf tobacco. Part 1 considered the effect of leaf size (cutstrip size vs. whole leaf), packing density and mode of leaf orientation on cured-leaf chemistry and leaf quality; whereas, the present study considers further the effect of leaf form, two yellowing times and two drying potentials during yellowing. Results showed that leaf chemistry and quality were quite similar for cut strip $(15.2 \times 22.9 \mathrm{~cm})$ and whole leaf. Insignificant differences were noted for curedleaf starch and sugars, although slightly lower levels of alkaloids (significant at the 0.01 level) were observed for cut strip. Curing treatments significantly affected leaf chemistry. Increased yellowing time resulted in lower levels of starch and higher levels of sugar. Sugars were also higher for tobacco yellowed under the higher drying potential. The two forms of leaf responded similarly to different curing schedules (i.e. no interaction of leaf form with schedule). Also, government grade and price data were essentially unaffected by leaf form or curing schedule over the range of variables tested.

Cured-leaf starch was abnormally high on the average for both leaf forms. Interestingly, starch levels were lower when intact tobacco was bulk cured in racks rather than box cured (6.35\% vs. $9.02 \%)$. Since curing schedules were similar, air velocity in the two curing methods might be a factor. Also the cured-leaf starch content was about $56 \%$ lower for tobacco produced at the Oxford Tobacco Research Station (in a secondary study) than at the Central Crops Research Station. It is postulated that carbohydrate and nitrogen metabolism during growth and maturation might be affected by excess rainfall events and/or nitrogen availability, with subsequent effects on starch-to-sugar conversion during curing. [Beitr. Tabakforsch. Int. 20 (2002) 61-67]

\section{ZUSAMMENFASSUNG}

Bei der vorliegenden Arbeit handelt es sich um Teil 2 einer vergleichenden Studie über die Behandlung und Trocknung von in Streifen geschnittenem Tabak im Vergleich zu ganzen Tabakblättern. Der erste Teil befasste sich mit der Auswirkung der Blattgröße (Größe der Streifen im Vergleich zu ganzen Blättern), der Packungsdichte und der Art der Orientierung auf die chemischen Eigenschaften und die Qualität der getrockneten Tabakblätter, während die vorliegende Arbeit die Auswirkung der Blattform, sowie von zwei Zeitphasen des Gelbwerdens und von zwei Trocknungspotentialen während des Gelbwerdens näher untersucht. Die Ergebnisse haben gezeigt, dass die chemischen Eigenschaften und die Qualität von Strips $(15.2 \times 22.9 \mathrm{~cm})$ und ganzen Blättern sehr ähnlich waren. Die Unterschiede bezüglich des Stärke- und Zuckergehalts getrockneter Tabakblätter waren nicht signifikant, während der Alkaloidgehalt bei den Tabakstrips im Vergleich zu ganzen Tabakblättern etwas niedriger war (Signifikanzniveau 0.01). Die Art der Trocknung hatte signifikante Auswirkungen auf die Blattchemie. Eine längere Phase des Gelbwerdens führte $\mathrm{zu}$ einem niedrigeren Stärke- und einem höheren Zuckergehalt. Der Zuckergehalt war bei Tabaken, die unter dem stärkeren Trocknungspotential gelb wurden, ebenfalls höher. Die zwei Blattformen zeigten bei den unterschiedlichen Trocknungsprogrammen die glei- 
chen Reaktionen (d.h. kein Zusammenhang zwischen Blattform und Trocknungsprogramm). Außerdem standen die amtlich festgesetzten Grade und Marktpreise in der Regel bezüglich der untersuchten Parameter mit der Blattform oder dem Trocknungsprogramm nicht in Beziehung.

Der Stärkegehalt getrockneter Tabakblätter war im Durchschnitt bei beiden Blattformen ungewöhnlich hoch. Interessanterweise war der Stärkegehalt von ganzen Tabakblättern bei Bulktrocknung auf Gestellen niedriger als bei Trocknung in Kisten (6.35\% vs. 9.02\%). Da die Trocknungsprogramme identisch waren, könnten unterschiedliche Luftströme bei beiden Trocknungsverfahren hierfür verantwortlich sein. Der Stärkegehalt getrockneter Blätter war außerdem bei Tabak, der (in einer nachfolgenden Untersuchung) in der Oxford Tobacco Research Station produziert wurde, ungefähr $56 \%$ niedriger als bei Tabak aus der Central Crops Research Station. Es wird postuliert, dass der Kohlehydrat- und Stickstoffmetabolismus während des Wachstums und der Reifung durch starke Regenfälle und/oder Stickstoffverfügbarkeit beeinflussen worden sein könnte mit nachfolgenden Auswirkungen auf die Umwandlung von Stärke in Zucker während der Trocknung. [Beitr. Tabakforsch. Int. 20 (2002) 61-67]

\section{RESUME}

Cette étude est la seconde partie d'une étude comparative sur les effets de la manipulation et le séchage du tabac découpé par rapport aux feuilles entières. La première partie a démontré l'effet de la taille des feuilles (taille des strips par rapport aux feuilles entières), la densité d'emballage et le mode d'orientation sur la chimie et la qualité des feuilles séchées. Cette étude examine l'effet de la forme des feuilles, de deux durées de jaunissement et deux régimes de séchage aux cours du jaunissement. Les résultats montrent que les caractéristiques chimiques et la qualité des morceaux de feuilles (d'une taille de $15.2 \times$ $22.9 \mathrm{~cm}$ ) sont pratiquement similaires à celle des feuilles entières. Les différences entres les deux types de feuilles ne sont pas significatives pour la teneur en amidon et en sucres, cependant la teneur en alcaloïdes est légèrement plus faible (significative à $0.01 \%$ ) chez le tabac découpé. Les modes de séchage exercent un effet significatif sur la chimie des feuilles. Une durée de jaunissement plus longue entraîne une teneur plus faible en amidon et une teneur plus élevée en sucres. La teneur en sucres est également plus élevée chez le tabac jauni sous le régime de séchage accru. Les deux formes de feuilles réagissent de la même façon aux différents programmes de séchage (absence de relation entre forme de feuilles et programme de séchage). De plus, les grades officiels et les prix du marché ne sont pas influencés dans la gamme de variables examinées par les types de feuilles examinées ou par le programme de séchage utilisé.

La teneur en amidon des feuilles séchées a été exceptionnellement élevée en moyenne chez les deux types de feuilles. Il est intéressant de noter que les teneurs en amidon se révèlent plus faibles si les feuilles entières sont séchées en masse dans des peignes plutôt que dans des caisses (6.35\% par rapport à 9.02\%). Comme les programmes de séchage étaient identiques, les flux d'air pourraient être responsable de ces différences. De plus, la teneur en amidon dans les feuilles séchées est de $56 \%$ plus faible chez le tabac de la station de recherche «Oxford Tobacco Research» (dans une étude consécutive) que chez le tabac produit à la «Central Crops Research Station». On fait donc l'hypothèse que le métabolisme des hydrates de carbones et de l'azote pourrait être affecté au cours de la croissance et la maturation par des pluies excessives et/ou par la disponibilité de l'azote, avec des effets ultérieurs sur la conversion de l'amidon en sucre au cours du séchage. [Beitr. Tabakforsch. Int. 20 (2002) 61-67]

\section{INTRODUCTION}

During 1996, an expanded research effort was undertaken to explore in greater depth the comparative properties of cut-strip and intact tobacco (1). Previous research had demonstrated several potential advantages of cut strip in comparison with intact leaves $(2,3,4)$. The cut-strip material, e.g. in $7.6 \times 7.6 \mathrm{~cm}$ or $7.6 \times 15.2 \mathrm{~cm}$ strips, had been observed to provide more uniform filling of curing box containers and dried more rapidly and uniformly during curing. Also, the cut-strip tobacco was found to pack inherently to a greater packing density than intact leaf, with up to $50 \%$ increased barn capacity in on-farm tests during 1995 (5). A major concern addressed in the present (1997) study relates to the chemistry of the cured cut-strip tobacco compared to cured whole leaf. Studies conducted during the 1970s and in 1994 and 1995 indicated that sugar contents may be lower for the cut-strip material while starch contents may be higher, although leaf color and grades appeared similar (2,5). In the1996 study (Part 1 of the present study), major variables tested were leaf form $(15.2 \times 7.6 \mathrm{~cm}, 15.2$ $\times 15.2 \mathrm{~cm}, 15.2 \times 22.9 \mathrm{~cm}$ leaf strips, and whole leaf) and packing density $\left(194,243\right.$ and $\left.292 \mathrm{~kg} / \mathrm{m}^{3}\right)$. Results showed that cured-leaf chemistry of the larger size of cut strip compared more closely with that of whole leaf (1). No consistent trend was noted for cured-leaf sugar in relation to strip size, although higher packing densities appeared to reduce sugars slightly for all leaf sizes. Total alkaloid levels were close and insignificantly different for the larger strip size and whole leaf; however, their values were significantly higher than values for the two smaller strip sizes. Similarly, cured-leaf starch contents were insignificantly different for the larger strip size and whole leaf; however, their values were significantly lower than those for the two smaller strip sizes. In general, packing density had little effect on curedleaf properties.

While considerable progress was made in 1996 in providing insight into the dynamics of leaf chemistry for cut strip vs. whole leaf, continued research is needed to determine the effect of major curing variables on comparative leaf analyses. In particular, yellowing time and drying potential during yellowing are variables that could influence starch hydrolysis and, consequently, levels of starch and sugars in cured leaf. It is well known that starch-to-sugar conversion is a major chemical reaction during the curing process, with total sugars increasing up to $20 \%$ or higher, with a corre- 
sponding decrease in starch content $(6,7,8)$. GoINS (7) found that starch hydrolysis was complete in many stalk positions between 36 and $48 \mathrm{~h}$; however other researchers have found that longer time periods may be required (6). Chlorophyll degradation occurs simultaneously with starch hydrolysis and unmasks the yellow pigments. Since this color change is an independent reaction, leaf color may not in itself indicate accurately the extent of starch hydrolysis with time of cure. Chlorophyll disappearance may be complete in as few as $36 \mathrm{~h}$; but it varies considerably with variety, maturity and leaf position with up to $72 \mathrm{~h}$ often required $(9,10)$. Also since available cellular water is considered necessary for most biochemical reactions, then drying potential of the yellowing environment could alter leaf moisture content and perhaps rate or extent of starch hydrolysis. For example premature drying along edges of cut-strip tobacco might result in higher cured-leaf starch content. On the basis of the above, it was, therefore, of interest to examine the chemical responses of intact and cutstrip leaf tobacco to variables of yellowing time and drying potential. This information is considered essential to the potential future application of the cut-strip curing concept.

\section{Objectives}

The long-term objective of this research investigation was to improve efficiencies of harvesting, handling, and curing through the development of higher capacity systems that utilize potential advantages of cut strip in comparison with whole leaf. The cured cut-strip product must maintain high quality standards associated with US leaf and must be acceptable to leaf processors and cigarette manufacturers. The short-term objective was to determine the effect of yellowing time and drying potential on chemical changes and cured-leaf properties of cut-strip vs. whole-leaf tobacco.

\section{MATERIALS AND METHODS}

A primary research experiment was conducted at the Central Crops Research Station, Clayton, NC, with a secondary experiment conducted at the Oxford Tobacco Research Station, Oxford, NC.

\section{Equipment development}

The general description of the handling and curing equipment was provided previously (1). Equipment was further developed or modified to enhance achievement of objectives by reducing air leakage for better humidity control, providing modified dampers for better control of air intake, and replacing single-stage electrical heaters with three-stage units to reduce air-temperature variation. In operation, the second- or third-stage heaters were automatically energized by computer control when the inlet dry-bulb temperature was below the set-point temperature for specified times. Larger box curing containers $(1.33 \mathrm{~m}$ wide $\times 0.8 \mathrm{~m}$ deep $\times$ $1.41 \mathrm{~m}$ high) were built, which are more representative of on-farm conditions. Each curing barn held two curing containers rather than four as in 1996. Similarly, new box containers were provided for the small barns at Oxford, which were about the same size as the barns at the Central Crops Research Station. Each barn there held two boxes of dimensions $1.35 \mathrm{~m}$ wide $\times 0.71 \mathrm{~m}$ deep $\times 1.41 \mathrm{~m}$ high . Refinements were also made in regards to handling equipment. Cutting equipment was further improved to enable more precise positioning of the cross-cutter with respect to the bed knife, which assured a better cutting action. Conveyor and distribution equipment were modified for improved reliability and distribution of material into the containers. New belting and bearings were installed, and an oscillating vane for distributing tobacco into the containers was provided. Also, an electronic weigh system was installed at both locations to permit precise loading of containers to the desired packing density. In fact, rather than weighing tobacco prior to placement into containers, tobacco was weighed directly during filling of containers.

\section{Procedures}

Field experiments were conducted from July 28 to late October. For the primary experiment at Clayton, treatments tested included 1) two leaf forms, $15.2 \times 22.9 \mathrm{~cm}$ cut strip vs. whole leaf, at a packing density of $243 \mathrm{~kg} / \mathrm{m}^{3}$; 2) two yellowing times, normal (Y1) and 4/3 normal (Y2); and 3) two drying potentials, normal (D1) and increased drying (D2) during yellowing. Nicotiana tabacum L., cv. K 326 was produced at both research locations (1.42 ha at Clayton, 1.21 ha at Oxford). The Oxford Tobacco Research Station experiment included the treatment of $4 / 3$ normal yellowing time (Y2) at normal drying during yellowing (D1) plus other temperature-humidity conditions of yellowing which were used in a separate study. In each case, the curing barn held two containers, one with whole leaf and the other with $15.2 \times 22.9 \mathrm{~cm}$ cut-strip tobacco, which enabled direct comparison of the two leaf forms.

Treatment randomization at the Central Crops Research Station was made in regards to field plot selection, barn selection, and curing schedule for a given barn to reduce experimental error.

The general procedure for a given week of harvest at the Central Crops Research Station was as follows. Tobacco was harvested by hand (about 3 leaves/plant) and hauled by trailer to the curing barns. The $15.2 \times 22.9 \mathrm{~cm}$ cut-strip and whole-leaf treatments were interchanged weekly as to location within a barn. Tobacco was placed on the cutter conveyor (for the cut-strip treatment), cut into sized pieces, elevated and distributed into the box containers to the specified packing density. At $243 \mathrm{~kg} / \mathrm{m}^{3}$ packing density, the boxes held $360.6 \mathrm{~kg}$. Intact leaf by-passed the cutter and moved directly into the elevator/distributor. Some redistribution of tobacco was made as necessary to obtain uniform filling, especially along sides and corners of the boxes. Tobacco was weighed electronically to within $0.2 \mathrm{~kg}$ during filling of containers. Three green samples were taken directly from each container (near bottom, middle and top) during filling of boxes for starch analyses. Boxes were closed, rods inserted at specified locations (about $19 \mathrm{~cm}$ apart in rows spaced 23 $\mathrm{cm}$ apart from bottom to top of container), and boxes lifted by gantry and moved to the loading ramp, then rolled into the curing barns. Foam rubber was used to seal any openings 
Table 1. Percent starch content for green and cured samples at the Central Crops Research Station. Values shown represent averages over three replications (sampling locations) per cured lot, and further averaged over cures 1 to 6 . Cut strip was processed at $15.2 \times 22.9 \mathrm{~cm}$.

\begin{tabular}{|c|c|c|c|c|c|}
\hline \multirow[b]{2}{*}{ Leaf form } & \multicolumn{4}{|c|}{ Curing schedule $^{a}$} & \multirow[b]{2}{*}{ Average } \\
\hline & Y1-D1 & Y1-D2 & Y2-D1 & Y2-D2 & \\
\hline \multicolumn{6}{|c|}{ Green samples (\%starch) } \\
\hline Cut strip & 28.73 & 29.55 & 30.33 & 31.14 & 29.94 a \\
\hline Whole leaf & 31.43 & 33.98 & 32.43 & 32.81 & $32.66 \mathrm{~b}$ \\
\hline Average & 30.08 & 31.77 & 31.38 & 31.97 & 31.30 \\
\hline Means & \multicolumn{5}{|c|}{ Y1: 30.93; Y2: 31.68; D1: 30.73; D2: 31.87} \\
\hline \multicolumn{6}{|c|}{ Cured samples (\%starch) } \\
\hline Cut strip & 9.95 & 10.58 & 9.48 & 8.58 & 9.65 \\
\hline Whole leaf & 9.50 & 9.06 & 9.06 & 8.46 & 9.02 \\
\hline Average & 9.72 & 9.82 & 9.27 & 8.52 & 9.33 \\
\hline Means & \multicolumn{5}{|c|}{ Y1: 9.77 a; Y2: 8.90 b; D1: 9.50; D2: 9.17} \\
\hline
\end{tabular}

${ }^{a} Y 1=$ normal yellowing time; $Y 2=4 / 3$ normal yellowing time; $\mathrm{D} 1=1.8^{\circ} \mathrm{C}$ depression; $\mathrm{D} 2=2.8^{\circ} \mathrm{C}$ depression.

${ }^{b}$ Within green or cured samples, average values with different letters $(\mathrm{a}, \mathrm{b})$ were significantly different at $P=0.05$.

along the rear and front walls as considered necessary. After filling all four barns, the barns were closed and curing placed under computer control to the four designated curing schedules (treatments). Generally, curing was accomplished following schedules of $35^{\circ} \mathrm{C}$ dry bulb, 33.3 or $32.2{ }^{\circ} \mathrm{C}$ wet bulb for yellowing over a normal vs. $4 / 3$ normal period, followed by gradual elevation of dry-bulb temperature to about $57^{\circ} \mathrm{C}$ with lowered humidity during leaf drying; and with final stem drying at $74^{\circ} \mathrm{C}$. Wet-bulb temperatures of 33.3 and $32.2{ }^{\circ} \mathrm{C}$ provided temperature differentials, relative to the dry-bulb temperature of $35^{\circ} \mathrm{C}$, of 1.7 and $2.8{ }^{\circ} \mathrm{C}$, respectively, or two drying potentials (D1 and D2) during yellowing. Similarly, the normal yellowing time (Y1) varied between around 48 to $72 \mathrm{~h}$. Hence, if the normal yellowing time was $48 \mathrm{~h}$, then the second yellowing time treatment (Y2) was $4 / 3 \times 48$, or $64 \mathrm{~h}$. A total curing time of about 6 to $7 \mathrm{~d}$ was typically required for the four curing treatments. Following curing, the tobacco was conditioned either by computer or manual control of the spray nozzles to about 16-18\% (wet basis) to permit handling without leaf shatter. Conditioned tobacco was unloaded, weighed, and sampled at bottom, middle and top locations for chemical analyses; then placed in burlap sheets for storage.

Procedures at the Oxford Tobacco Research Station were similar to those at the Central Crops Research Station; however, this location should be considered observational only for several reasons. The tobacco was a very late crop, with harvest beginning on September 12, or about a month late. Also, three of the four barns at this location were dedicated to thesis research and the more mature, better quality tobacco was generally made available for the whole leaf used in the study. Cut strip was cured alongside whole leaf although the tobaccos differed somewhat in stalk position or maturity. In addition, curing conditions covered a wide range of temperature and relative humidity during yellowing which could cause more rapid drying along edges of cut-strip material. Nevertheless, it was of interest to obtain chemical and subjective comparisons as were done for the Central Crops Research Station experiment. Six harvests representing all stalk positions were made from July 28 to September 24 at the Central Crops Research Station; whereas, seven harvests were made at the Oxford Tobacco Research Station from September 12 to October 24.

Green- and cured-leaf samples taken from each curing container were evaluated for select chemical constituents including starch, reducing sugar, and total alkaloids by the Tobacco Chemistry Laboratory at North Carolina State University (NCSU). Assignment of government grades was made by the United States Department of Agriculture (USDA) district grading supervisor for each cured lot of tobacco. A SAS General Linear Model Procedure was used to analyze the data for statistical significance.

\section{RESULTS}

\section{Equipment performance}

The cutter worked well with little evidence of excessive bruising due to the cutting action or mechanical handling. Other equipment including conveyor, distributor, loading equipment, and curing barns worked well. A few minor problems were experienced with the computer-control system, but these were quickly identified and resolved without serious consequences to the cures in progress. Curing schedules achieved were relatively close to those programmed into the computer, with normal variance of about 0.5 to $1.0^{\circ} \mathrm{C}$ around set points due to heater on and off cycling and damper actuation.

\section{Chemical analyses}

Table 1 presents green- and cured-leaf starch contents, averaged over cures 1 to 6 for research at the Central Crops Research Station. Statistical analyses were conducted for both sets of data, although one would not expect any significance due to treatments prior to curing. Green-leaf starch contents were quite variable, particularly with stalk position, ranging from a high average of 57\% for harvest two to $16 \%$ for harvest six. The overall average for green samples was about $31 \%$. In addition to cure testing significant at the $0.01 \%$ level, leaf form tested significant at the $0.05 \%$ level. Note that green-leaf starch contents were $29.94 \%$ for the $15.2 \times 22.9 \mathrm{~cm}$ form and $32.66 \%$ for whole leaf. No explanation is available for these differences. It may be that sampling of cut pieces somehow led to selection of pieces that had lower starch content. Curing schedule variables (Y, D) tested not significant for green-leaf starch content. Curedleaf starch contents varied from a high average of $15.7 \%$ for cure three to $5.52 \%$ for cure six. As expected, cure (leaf position) was highly significant at the $0.01 \%$ level. Leaf 
Table 2. Percent reducing sugar and total alkaloid contents for cured samples at the Central Crops Research Station. Values shown represent averages over three replications (sampling locations) per cured lot, further averaged over cures 1 to 6 . Cut strip was processed at $15.2 \times 22.9 \mathrm{~cm}$.

\begin{tabular}{|c|c|c|c|c|c|}
\hline \multirow[b]{2}{*}{$\underline{\text { Leaf form }}$} & \multicolumn{4}{|c|}{ Curing schedule $^{a}$} & \multirow[b]{2}{*}{ Average $^{b}$} \\
\hline & Y1-D1 & Y1-D2 & Y2-D1 & Y2-D2 & \\
\hline \multicolumn{6}{|c|}{$\%$ Reducing sugar } \\
\hline Cut strip & 12.08 & 11.97 & 11.99 & 12.51 & 12.14 \\
\hline Whole leaf & 11.11 & 12.58 & 12.25 & 12.52 & 12.12 \\
\hline Average & 11.59 & 12.27 & 12.12 & 12.52 & 12.13 \\
\hline Means $^{b}$ & \multicolumn{5}{|c|}{ Y1: 11.93; Y2: 12.32; D1: 11.86 a; D2: 12.39 b } \\
\hline \multicolumn{6}{|c|}{$\%$ Total alkaloid } \\
\hline Cut strip & 2.36 & 2.25 & 2.38 & 2.33 & $2.33 \mathrm{a}$ \\
\hline Whole leaf & 2.38 & 2.45 & 2.41 & 2.43 & $2.42 \mathrm{~b}$ \\
\hline Average & 2.37 & 2.35 & 2.39 & 2.38 & 2.38 \\
\hline Means & \multicolumn{5}{|c|}{ Y1: 2.36; Y2: 2.39; D1: 2.38; D2: 2.37} \\
\hline
\end{tabular}

${ }^{\mathrm{a}} \mathrm{Y} 1=$ normal yellowing time; $\mathrm{Y} 2=4 / 3$ normal yellowing time; $\mathrm{D} 1=1.8^{\circ} \mathrm{C}$ depression; $\mathrm{D} 2=2.8^{\circ} \mathrm{C}$ depression.

${ }^{\mathrm{b}}$ Average values with different letters $(\mathrm{a}, \mathrm{b})$ were significantly different at $P=0.05$ for reducing sugar and $P=0.01$ for total alkaloid.

form $(15.2 \times 22.9 \mathrm{~cm}$ vs. whole leaf $)$ and drying potential during yellowing (D1, D2) tested not significant; however, yellowing time (Y1, Y2) tested significant at the $0.05 \%$ level. Extending the yellowing time to $4 / 3$ normal (Y2) reduced cured-leaf starch on average from $9.77 \%$ to $8.90 \%$, which is not large numerically but is consistent with expecta- tions. No leaf form by curing variable $(Y, D)$ interactions were noted.

Table 2 presents percent reducing sugars and total alkaloids for cured-leaf samples from studies at the Central Crops Research Station, averaged over cures 1 to 6. Average cure values for reducing sugar ranged from $11.9 \%$ to $15.7 \%$, with an overall average of $12.13 \%$. Leaf form and yellowing time tested not significant at the $0.05 \%$ level; although sugars were slightly higher for the longer yellowing time $(12.32 \%$ vs. $11.93 \%)$. On the other hand, cure and drying potential did test significant at $0.01 \%$ and $0.05 \%$ levels, respectively. Sugars were slightly higher (12.39\% vs. $11.86 \%$ ) when yellowed at the $2.8^{\circ} \mathrm{C}$ differential (D2). For total alkaloids, average cure values ranged from $1.21 \%$ to $3.73 \%$, with higher values for upper stalk tobacco. The overall average for total alkaloids was $2.38 \%$. Although curing schedule treatments (yellowing time and drying potential during yellowing) tested not significant, cure and leaf form both tested significant at the $0.01 \%$ level. The $15.2 \times 22.9 \mathrm{~cm}$ cut strip averaged slightly lower in total alkaloids than the whole leaf $(2.33 \%$ vs. $2.42 \%)$. These differences are considered to be small and may reflect slightly less dry matter loss during curing for the cut-strip tobacco, since alkaloids are normally considered fairly stable during curing. No leaf form by curing variable (Y, D) interactions were found for either sugars or alkaloids.

\section{Grade and price evaluations}

Table 3 shows the USDA grade and price support summary for cured cut-strip and whole-leaf (WL) tobacco for cures 1 to 6 at the Central Crops Research Station. Within a given cure, the grades were very close or essentially the same among the various treatment lots. Neither leaf form

Table 3. USDA grade and price support summary for cured cut-strip $(15.2 \times 22.9 \mathrm{~cm})$ and whole leaf $(\mathrm{WL})$ tobacco, cures 1 to 6, at the Central Crops Research Station

\begin{tabular}{|c|c|c|c|c|c|c|c|c|c|}
\hline \multirow[b]{3}{*}{ Cure } & \multirow[b]{3}{*}{ Leaf form } & \multicolumn{8}{|c|}{ Curing schedule } \\
\hline & & \multicolumn{2}{|r|}{ Y1-D1 } & \multicolumn{2}{|r|}{ Y2-D2 } & \multicolumn{2}{|r|}{ Y2-D1 } & \multicolumn{2}{|r|}{ Y2-D2 } \\
\hline & & Grade & Price US\$/kg & Grade & Price US\$/kg & Grade & Price US\$/kg & Grade & Price US\$/kg \\
\hline 1 & $\begin{array}{l}\text { Cut strip } \\
\text { WL }\end{array}$ & $\begin{array}{l}\text { SX4KL } \\
\text { X3F }\end{array}$ & $\begin{array}{l}3.57 \\
3.66\end{array}$ & $\begin{array}{l}\text { SP4L } \\
\text { X4L }\end{array}$ & $\begin{array}{l}3.44 \\
3.57\end{array}$ & $\begin{array}{l}\text { SX4L } \\
\text { P3L }\end{array}$ & $\begin{array}{l}3.57 \\
3.53\end{array}$ & $\begin{array}{l}\text { SP4L } \\
\text { X3F }\end{array}$ & $\begin{array}{l}3.44 \\
3.66\end{array}$ \\
\hline 2 & $\begin{array}{l}\text { Cut strip } \\
\text { WL }\end{array}$ & $\begin{array}{l}\text { SC4KL } \\
\text { C4KL }\end{array}$ & $\begin{array}{l}3.84 \\
3.84\end{array}$ & $\begin{array}{l}\text { SC4KL } \\
\text { C4KL }\end{array}$ & $\begin{array}{l}3.84 \\
3.84\end{array}$ & $\begin{array}{l}\text { SC4KL } \\
\text { C4KL }\end{array}$ & $\begin{array}{l}3.84 \\
3.84\end{array}$ & $\begin{array}{l}\text { SC4KL } \\
\text { C4KL }\end{array}$ & $\begin{array}{l}3.84 \\
3.84\end{array}$ \\
\hline 3 & $\begin{array}{l}\text { Cut strip } \\
\text { WL }\end{array}$ & $\begin{array}{l}\text { SB4KL } \\
\text { B4KL }\end{array}$ & $\begin{array}{l}3.95 \\
3.95\end{array}$ & $\begin{array}{l}\text { SB4KL } \\
\text { B4KL }\end{array}$ & $\begin{array}{l}3.95 \\
3.95\end{array}$ & $\begin{array}{l}\text { SB4KL } \\
\text { B4KL }\end{array}$ & $\begin{array}{l}3.95 \\
3.95\end{array}$ & $\begin{array}{l}\text { SB4KL } \\
\text { B4KL }\end{array}$ & $\begin{array}{l}3.95 \\
3.95\end{array}$ \\
\hline 4 & $\begin{array}{l}\text { Cut strip } \\
\text { WL }\end{array}$ & $\begin{array}{l}\text { SB4F } \\
\text { B3F }\end{array}$ & $\begin{array}{l}4.12 \\
4.12\end{array}$ & $\begin{array}{l}\text { SB3F } \\
\text { B3F }\end{array}$ & $\begin{array}{l}4.15 \\
4.15\end{array}$ & $\begin{array}{l}\text { SB4F } \\
\text { B4F }\end{array}$ & $\begin{array}{l}4.12 \\
4.12\end{array}$ & $\begin{array}{l}\text { SB3F } \\
\text { B3F }\end{array}$ & $\begin{array}{l}4.15 \\
4.15\end{array}$ \\
\hline 5 & $\begin{array}{l}\text { Cut strip } \\
\text { WL }\end{array}$ & $\begin{array}{l}\text { SB3K } \\
\text { B3K }\end{array}$ & $\begin{array}{l}4.10 \\
4.10\end{array}$ & $\begin{array}{l}\text { SB3K } \\
\text { B3K }\end{array}$ & $\begin{array}{l}4.10 \\
4.10\end{array}$ & $\begin{array}{l}\text { SB3K } \\
\text { B3K }\end{array}$ & $\begin{array}{l}4.10 \\
4.10\end{array}$ & $\begin{array}{l}\text { SB3K } \\
\text { B3K }\end{array}$ & $\begin{array}{l}4.10 \\
4.10\end{array}$ \\
\hline 6 & $\begin{array}{l}\text { Cut strip } \\
\text { WL }\end{array}$ & $\begin{array}{l}\text { SB4K } \\
\text { B5K }\end{array}$ & $\begin{array}{l}4.08 \\
4.03\end{array}$ & $\begin{array}{l}\text { SB5K } \\
\text { B5K }\end{array}$ & $\begin{array}{l}4.03 \\
4.03\end{array}$ & $\begin{array}{l}\text { SB5K } \\
\text { B5K }\end{array}$ & $\begin{array}{l}4.03 \\
4.03\end{array}$ & $\begin{array}{l}\text { SB5K } \\
\text { B5K }\end{array}$ & $\begin{array}{l}4.03 \\
4.03\end{array}$ \\
\hline Means & $\begin{array}{l}\text { Cut strip } \\
\text { WL }\end{array}$ & & $\begin{array}{l}3.94 \\
3.95\end{array}$ & & $\begin{array}{l}3.92 \\
3.94\end{array}$ & & $\begin{array}{l}3.94 \\
3.93\end{array}$ & & $\begin{array}{l}3.92 \\
3.95\end{array}$ \\
\hline Test means & $\begin{array}{l}\text { Cut strip }= \\
W L=3.94\end{array}$ & & & $\begin{array}{l}\mathrm{Y} 1=3 . \\
\mathrm{Y} 2=3 .\end{array}$ & & & $\begin{array}{l}\text { D1 }=3.94 \\
\text { D2 }=3.93\end{array}$ & & \\
\hline
\end{tabular}


Table 4. Comparison of research results from the Central Crops Research Station and the Oxford Tobacco Research Station. Averages are shown for the entire curing season.

\begin{tabular}{|c|c|c|c|c|c|}
\hline \multirow[b]{2}{*}{ Analysis } & \multicolumn{3}{|c|}{$\begin{array}{c}\text { Central Crops Research Station (6 cures) } \\
\text { Leaf form }\end{array}$} & \multicolumn{2}{|c|}{$\begin{array}{c}\text { Oxford Tobacco Research Station (7 cures) } \\
\text { Leaf form }\end{array}$} \\
\hline & Cut strip & WL & WL (racks) & Cut strip & WL \\
\hline \%Starch, uncured & 29.94 & 32.66 & - & - & $29.37^{a}$ \\
\hline$\%$ Starch, cured & 9.65 & 9.02 & 6.35 & 4.32 & 4.00 \\
\hline \%Reducing sugars & 12.14 & 12.12 & 13.47 & 9.73 & 10.71 \\
\hline \%Total alkaloids & 2.33 & 2.42 & 2.36 & 2.88 & 2.73 \\
\hline Price/kg (US\$/kg) & 3.94 & 3.95 & - & 3.74 & 3.79 \\
\hline
\end{tabular}

astarch analyses for cures 1 to 6 only.

nor curing schedule seemed to affect government grades of cured tobacco for a given cure. The latter implies that the normal yellowing time was adequate to permit complete chlorophyll degradation and that there is some latitude to coloring time and wilting during yellowing without affecting subjective grades. Means for test variables showed less than US $\$ 0.04$ variation in price per $\mathrm{kg}$ values.

\section{Comparison of data from the Central Crops Research Station and the Oxford Tobacco Research Station}

Table 4 shows an overall comparison of various data from the two research stations. First it is noticed that green-leaf starch contents for the two locations averaged about the same over cures 1 to 6 . On the other hand, the cured-leaf starch content was about 56\% lower for the Oxford Tobacco Research Station than for the Central Crops Research Station ( $4.0 \%$ to $4.32 \%$ vs. $9.02 \%$ to $9.65 \%$ for boxcured leaf). Interestingly, the starch content for rack-cured tobacco at the Central Crops Research Station was lower than for box-cured tobacco $(6.35 \%$ vs. $9.02 \%$ for whole leaf). Reducing sugars appeared a little lower and the total alkaloids a little higher for tobacco produced at Oxford. Leaf quality was lower at the Oxford Tobacco Research Station as reflected by average price $/ \mathrm{kg}$. Cut-strip prices were lower than whole leaf at the Oxford Tobacco Research Station by about US $\$ 0.05 / \mathrm{kg}$, but this is closer than expected, considering the fact that the other study (whole leaf for thesis research) received the better quality tobacco at harvest.

Comparing the chemical data for cut strip vs. whole leaf at Oxford, it is noted that differences were relatively small. Starch and alkaloids were a little higher for the cut strip, whereas sugars were lower by about one percent. Statistical analyses showed that all three constituents differed statistically at the $0.05 \%$ level between the two leaf forms. This is not unexpected, inasmuch as there were differences in leaf quality going into the barns for the two leaf forms as noted earlier.

\section{DISCUSSION}

Perhaps of most significance for the 1997 research is that the Central Crops Research Station data indicates no significant differences between $15.2 \times 22.9 \mathrm{~cm}$ cut strip and whole leaf for cured leaf starch and sugars, with essentially identical government grades for the two leaf forms. Alkaloids were quite close, but significantly different at the $0.01 \%$ level. (The opposite trend for alkaloids was observed for the Oxford Tobacco Research Station tests). Also it is important to note that both forms of leaf responded the same to different curing schedules.

The fact, that overall cured-leaf starch levels at the Central Crops Research Station were abnormally high for both cut strip and whole leaf, deserves some comment. First, greenleaf starch contents appeared high, but not higher on average than the Oxford Tobacco Research Station tobaccos. It is postulated that, for some reason, rate of starch-tosugar conversion during curing was abnormally low, and that, even with extended yellowing, unconverted starch remained in the cured leaf. One possible explanation is that during growth and maturation, nitrogen availability was limiting (perhaps due to excess rainfall and/or inadequate applied nitrogen), which led to reduced accumulation of enzymes essential for carbohydrate hydrolysis during curing. Secondly, it is very interesting that rack-cured whole leaf had about 30\% lower cured-leaf starch than box-cured leaf. Since curing schedules were similar, air velocity differences (air flow $/ \mathrm{kg}$ dry wt.) in the two curing methods might be a causal factor.

As in previous studies, the cut-strip tobacco was found to distribute and pack more uniformly into containers than whole leaf. In addition, it was observed that the cut strip packed inherently to a higher packing density with a given amount of applied pressure.

\section{CONCLUSIONS}

On the basis of studies in 1996 and 1997, the potential for harvesting, handling and curing cut-strip tobacco to achieve cured-leaf qualities comparable to whole leaf has been established. Cured-leaf properties (starch, sugars, and alkaloids) of cut-strip tobacco sized to $15.2 \times 22.9 \mathrm{~cm}$ (or about $350 \mathrm{~cm}^{2}$ ) matched fairly closely the cured-leaf properties of whole leaf. Leaves cut into this strip size could very likely be successfully cured, marketed and utilized in the manufacture of cigarettes. On the other hand, the 1996 experiment showed that statistically significant 
differences were obtained when tobacco was cut into smaller strip sizes of $15.2 \times 7.6 \mathrm{~cm}$ or $15.2 \times 15.2 \mathrm{~cm}$. These differences may have resulted from greater bruising of the smaller cut-strip material during the cutting operation (1). Such differences might be reduced or eliminated by reducing impact velocity during the cross cutting operation prior to curing. Earlier studies have shown that starch degradation is impeded depending upon the degree or extent of bruising $(11,12)$.

Potential advantages of utilizing a cut-strip material include higher capacity in materials handling, greater uniformity in box filling/curing, higher packing densities, and more rapid and uniform drying. Translating these potential advantages into actual economic benefits will require scale-up and implementation of the concepts to a farm-scale operation. It is visualized, for example, that cutters could be placed on the mechanical harvester or could be used at the curing site. High capacity filling of containers could similarly be on the harvester or at the curing site. The major advantages would result from more uniform filling of large box containers to a higher packing density. Indications are that packing density could be easily increased $25 \%$ (or more) over that of whole leaf. On this basis and if one assumes that ultimately all US flue-cured tobacco were cured in cut-strip form, potential savings of curing barns alone would exceed US $\$ 15$ million/year in interest on investment. The complete economic scenario would entail considerations of additional equipment required, fuel savings due to increased throughput/barn, potential labor savings, etc. The advantages to the leaf processor would also need to be evaluated.

Acknowledgment: The authors wish to express appreciation to the following companies and Foundation for financial support provided for this research: Brown \& Williamson Tobacco Corporation, Lorillard Tobacco Company, Philip Morris USA, R. J. Reynolds Tobacco Company, and The North Carolina Tobacco Foundation, Inc.

\section{REFERENCES}

1. Johnson, W.H., J.H. Young, W.W. Weeks, G.H Ellington, and J.C. Tutor: Handling and curing characteristics of cut-strip tobacco. Part 1: Effect of strip size, packing density and mode of orientation; Beitr. Tabakforsch. Int. 20 (2002) 7-13.

2. Johnson, W.H.: Modular handling and curing studies - 1975; in: An Annual Report of Accomplishments in Tobacco Research in North Carolina, April 1 through March 31, 1976, Departmental Report of Biological and Agricultural Engineering, N.C. State University, Raleigh, N.C., 1976.
3. Johnson, W.H.: Tobacco processing system and method; U.S. Patent No. 3,885,376, 1975.

4. Johnson, W.H.: Tobacco handling and curing system and method; U.S. Patent No. 3,899,836, 1975.

5. Revels, J.E.: Investigation of cut-strip tobacco as a method to increase handling and curing efficiency of flue-cured tobacco; M.S. Thesis, Department of Biological and Agricultural Engineering, N.C. State University, Raleigh, N.C., 1997.

6. Abubakar, Y., J.H. Young, W.H. Johnson and W.W. Weeks: Changes in moisture and chemical composition of flue-cured tobacco during curing; Tob. Sci. (in review), 2001.

7. Goins, G.D., D.A. Danehower, A.R. Butler, K. Brock, and G.S. Miner: Influence of ethylene on curing of under ripe and ripe tobacco, I. Chemical changes during the yellowing phase of flue-curing; Tob. Sci. 40 (1996) 1-9.

8. Johnson, W.H.: Influence of harvesting and process variables on bulk curing of bright leaf tobacco; Trans. of the ASAE 8, No. 3 (1965) 354-357.

9. Gwynn, G.R. and W.F. McClure: Differences among tobacco varieties and breeding material in chlorophyll content during curing; Tob. Sci. 18 (1974) 1-3.

10. McClure, W.F.: Fiber-optic spectrophotometer for in vivo analysis of biological materials: chlorophyll measurements; Trans. of the ASAE 12, No. 3 (1969) 319-321.

11. Comber, R.: The effect of bruising on starch degradation in Virginia tobacco leaves; Beitr. Tabakforsch. 9 (1977) 53-57.

12. Johnson, W.H., F.J. Hassler, and W.H. Henson, Jr.: Effects of bruising on tobacco curability; Tob. Sci. 1 (1957) 177-179.

\section{Address for correspondence}

William H. Johnson

North Carolina State University

Department of Biological and Agricultural Engineering Box 7625

Raleigh, North Carolina 27695-7625, USA

e-mail addresswjohnson@unity.ncsu.edu. 